\title{
Same-sex relationships: A 1st-century perspective
}

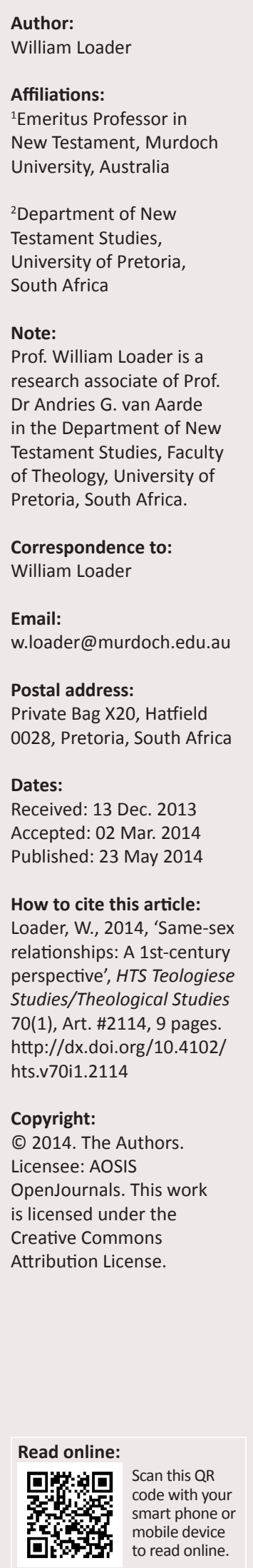

Read in the light of other Jewish literature of the time, not least, Philo of Alexandria, Paul's comments in Romans 1 about same-sex relations should be seen as a rhetorical ploy to gain a sympathetic hearing for his argument from the Roman recipients of his letter by appealing to common ground in deploring the sins of the Gentile world before turning to challenge them about the fact that all have sinned, and so need the good news of God's righteousness revealed in Christ. Typically Paul's focus is not just acts, but attitude and misdirected passions, which he sees as the result of misdirected and perverted understandings of God. Based on the Genesis creation stories, Paul assumes that all people are heterosexual and that the prohibitions of Leviticus should apply also to lesbian relations. Where these assumptions are not shared, Paul's conclusions must be revisited in the light of informed compassion and responsible ethical insight.

\section{Introduction}

It is somewhat fortuitous that we have in the New Testament (NT) some reference to same-sex relations. We have this because Paul wanted to cite what he could assume his hearers would most agree with him in condemning. He does so in order to introduce his argument that in fact all people fall under God's condemnation - not only those Gentiles, but also Jews. He packs very much into the four relevant verses in Romans (1:24, 26-28), but leaves much unexplained because it needed no explanation. Fortunately he is not the only Jew of his time to address the issue and other Jews were not so terse. I have discussed Jewish literature (Loader 2007, 2009, 2011a, 2011b, 2012:22-33), Greco-Roman literature (Loader 2012:83-91) and NT literature on the theme in extensive detail elsewhere (Loader 2012:293-338).

\section{Philo of Alexandria}

Our best resource for extensive Jewish comment is Paul's contemporary, Philo of Alexandria, who happily engages at the interface of Jewish and Hellenistic Roman culture in a way that enables us to recognise perspectives informing his thought from both sources. Whilst we cannot assume that Alexandria's Philo and Tarsus' Paul would have necessarily shared the same perspectives in such matters, it is clear that they have much in common, so that Philo provides a helpful entry into the biblical texts. He has the advantage of not being considered inspired and authoritative, and so being less laden with the distorting hopes and fears which that brings.

In his account of the Therapeuts, mostly people of senior age, men and women who live in celibacy on the shores of Lake Mareotis near Alexandria in reflection and contemplation, Philo contrasts their holy feasts with the unholy parties of his day. 'For waiting there', he writes, 'are slaves of the utmost comeliness and beauty, giving the idea that they have come not so much to render service as to give pleasure to the eyes of the beholders by appearing on the scene' (Contempl. 50). He then describes some 'who are still boys' and others 'full-grown lads fresh from the bath and smooth shaven, with their faces smeared with cosmetics and paint under the eyelids and the hair of the head prettily plaited and tightly bound' (Contempl. 50; similarly described in Spec. 3.37):

In the background are others, grown lads newly bearded with the down just blooming on their cheeks, recently pets of the pederasts, elaborately dressed up for the heavier services, a proof of the opulence of the hosts as those who employ them know, but in reality of their bad taste. (Contempl. 52)

He goes on to describe the gluttony and drunkenness typical of such occasions and the sexual profligacy which ensues (Contempl. 53-56; cf. also Abr. 134-135; Somn. 1.122-125; Ebr. 21). Elsewhere he describes the men at such parties as typically engaging in indiscriminate sex with both women and men or boys (Spec. 2.50; Legat. 14). He describes the men of Sodom similarly as engaged both in adultery and in mounting other men, as he puts it (Abr. 133-141). 
Already we see three important elements in Philo's discussion:

1. Same-sex acts happen primarily in wild drunken parties.

2. They are simply part of profligate sexual response: the same men also engage in adultery (similarly Josephus A.J. 3.275). Antony's profligacy illustrates the point (A.J. $15.25,30)$.

3. The passive partners are frequently slaves exploited for the purpose, made to look like women, functioning in many instances as male prostitutes, and ranging in age from puberty to maturity. At Sodom, Philo assumes adults are engaged in such acts. Sodom is associated with unnatural and strange sexual behaviour also in Her. 77; Fug. 144; Post. 52; Spec. 2.170; Mos. 2.55; and Conf. 40.

In the context of his discourse about the Therapeuts, Philo goes on to speak rather disparagingly of the Symposiums of Xenophon and of Plato, citing from the latter the myth of Aristophanes (Contempl. 57-63; cf. Xenophon, Symp. 2; Plato Symposium 189-193). The myth is an aetiology of sexuality ${ }^{1}$ according to which humans once existed as male, female, or androgynous. Because of the insolence of these humans, Zeus cut each in half so that the halves have sought each other ever since. Those deriving from the androgynous being have been seeking their opposite, thus men seeking women, and women, men. The other two produced the phenomenon of men seeking men as their other half, and women seeking women as their other half. This theory of the origins of heterosexuality and homosexuality, put by Plato on the lips of Aristophanes and not reflecting his own convictions, receives short shrift in Philo. Philo notes that it is 'seductive enough calculated by the novelty of the notion to beguile the ear', but to be treated by 'the disciples of Moses trained from their earliest years to love the truth ... with supreme contempt' (Contempl. 63). The disciples of Moses know that God made humankind male and female and that whilst their God also engaged in a kind of surgery, the creation of woman was not a rash stroke of anger but divine purpose. They also know that their Moses forbade lying with a man as with a woman, and declared it an abomination (Lv 18:22; 20:13). In his exposition of Mosaic law (Spec. 3.37-3.42), Philo not only cites the sentence of death mandated in Leviticus 20:13, but insists it should be immediate (Spec. 3.38).

Aristophanes's myth is evidence that some did indeed see what we would call a homosexual orientation as natural, but such belief was relatively rare, and unlikely to find any more assent amongst Jews in general than it did with Philo. Philo bolsters his conviction, rooted in the biblical prohibition, with arguments reflecting significant values of his day. He repeatedly depicts same-sex relations between men as demeaning, especially of the man taking the passive role, assuming anal intercourse. He speaks of feminisation of boys and young men, producing men who are effeminate, what he calls the $\theta \dot{\eta} \lambda \varepsilon 1 \alpha v$... vóбov [female disease] (Abr. 136; Prob. 124). This view is serious because women are inferior in his and his contemporaries' view. It is serious for other reasons, too.
Like Plato, Philo believed that such behaviour threatened the survival of the species. If semen is wasted - and their view was that it was in limited supply - and the semen available not planted in the fertile field of women's wombs, cities could be devastated through falling population (Contempl. 62; Spec. 3.32-33, 39; Abr. 136-137; Anim. 49); Pseudo-Aristeas asserts the same concern. More serious still, men made effeminate in this way become impotent according to Philo (Abr. 135; Spec. 3.37).

They also lose their virility in a broader sense, becoming weaklings - the very antithesis of what Roman culture hailed as the male ideal. Philo embraces the typical Roman disdain for what they called the Greek disease, especially its pederastic form (so also Josephus Ap. 2.269). Same-sex exploitation of young male citizens was stuprum, forbidden by Roman law. The Greeks in turn, despised the Roman practice of nevertheless engaging in same-sex relations with slaves and noncitizens past the age when men were expected to marry and produce offspring for society, the cut-off stage as Greeks saw it.

Both the shameful passive partner, reduced to the level of a woman, and the active male, subverting the order of nature, divine order, was to be condemned according to Philo. When he explores the grounds for such madness he returns to the excess of the wild parties, where men spurred on by alcohol, lose control of their passions, which then control them and produce their profligate behaviour (Spec. 3.40). He also deplores the social acceptance given such people in public ceremonies (Spec. 3.40-41). Although he makes little mention of it, Philo also condemns women similarly for acting contrary to their nature in lesbian pursuits ( $Q G$ 2.49; Virt. 20-21; Her. 274).

\section{Jewish literature beyond Philo}

Like idolatry, same-sex relations were seen as evils typical of pagan society as they had been for centuries, attested already in Leviticus 18 which warns against the practices:

You shall not do as they do in the land of Egypt, where you lived, and you shall not do as they do in the land of Canaan, to which I am bringing you. (v. 3)

Most allusions in the period under our consideration come from contexts where Jews faced the need for such demarcation. Thus Aristeas decries male prostitution, and fears depopulation as a result (152; cf. also 108, 130). PseudoPhocylides argues against both male and female same-sex intercourse (190-192) condemning it as an extension of the prohibition of adultery (3), and cautions parents about braiding boys' hair in the light of male sexual predators (210-214). He cites Plato's argument that not even in the animal kingdom does one find such behaviour - at least they thought so then (191, cf. Plato Leg. 836C).

The sibyl in Sibylline Oracles 3 lambasts Rome for its sexual exploitation and for its institutes of male prostitution (3:185$187,596-599,764)$, as later authors of books 4 (4:33-34) 
and 5 (5:166-168) target Rome for its 'adulteries and illicit intercourse with boys' as an 'effeminate and unjust, evil city' and 'unclean' (similarly 5:387; cf. also 5:430). 2 Enoch condemns 'sin which is against nature, which is child corruption in the anus in the manner of Sodom' (10:2) and the wickedness of those sowing worthless seed, including 'abominable fornications, that is, friend with friend in the anus, and every other kind of wicked uncleanness which it is disgusting to report' (34:1-2Ms P). Apoc. Abr. 24:8, describes what is apparently adult-to-adult male consensual samesex relations (i.e. not in anal intercourse) but where naked men stand forehead to forehead. Wisdom 14:26 is probably alluding to male same-sex relations, depicting it, like Paul as perversion, matching the perversion by idolaters of the true nature of God. There may be an allusion to lesbian relations in the surprising comment about Aseneth in Joseph and Aseneth, where after describing her being kept from male eyes, couped up in defensive towers and attended by seven virgins her own age, we read that no one, not even her virgin attendants, ever sat on her bed (2:9; Ph 2:16).

Josephus recounts the behaviour of Antony, fame consort of Cleopatra (A.J. 15.22-35). His agent visited Jerusalem and was so impressed with the beauty of Mariamme, Herod's Hasmonean wife, and with her brother, the 16-year-old Aristobulus, that he has paintings made of them (in the Jewish War he says the initiative was Mariamme's mother, Alexandra - B.J. 1.439). They so impressed Antony that he planned to summon both to Alexandria to meet his sexual predatory ambitions. Herod, shocked on hearing this, quickly sacked the high priest whom he had appointed and made Aristobulus high priest, an office which forbade his incumbent leaving the land. Antony finally came to his senses and pulled back from the outrageous ambition to sleep with Herod's wife. Antony's sexual predation was typical of the time - promiscuity directed to both women and men.

\section{The New Testament apart from Paul}

Before turning to Paul, let me note briefly that at most there is one further likely reference to same-sex relations in the NT, namely in the form of pederasty, in the warning attributed to Jesus against causing little ones to stumble, a word used also in sexual contexts (Mk 9:42). The warning comes along with stark advice to lop off limbs or pluck out eyes to prevent oneself sinning (9:43-48), applied by Matthew already in the Sermon on the Mount with specific reference to sexual wrongdoing (5:30). In addition, some may have heard the anecdote about people bringing children to Jesus that he may touch them (Mk 10:13-15), as offering them for sexual exploitation. They would then have interpreted the vehemence of the disciples' response in the light of that, but we have no evidence that it was heard this way. I do not see the saying about being a eunuch from birth (Mt 19:12) as referring to same-sex orientation. Eunuchs were impotent and could not sustain an erection, but could otherwise be sexually active in relation to both women and men and frequently were.

\section{Paul}

Aside from Romans we have reference to $\alpha \rho \sigma \varepsilon v о к о \tilde{\tau} \alpha \iota$ and $\mu \alpha \lambda \alpha \kappa o$. In the list of those excluded from the kingdom of God in 1 Corinthians 6:9-10; the words are best understood as referring to the active and passive partners in same-sex intercourse, 'male-bedders' and 'softies', a term used also more widely of effeminacy. The former word appears in the list found in the deutero-Pauline 1 Timothy 1:10 and may have been a neologism based on the Greek text of Leviticus 18:22.

\section{Same-sex relations in Paul's argument in Romans}

Turning to Romans, we have reference to same-sex relations in four verses, 1:24, 26-28, as part of a broader argument which reaches from 1:16 to 3:27. About to visit Rome, whose Christian community was founded by others and where people had heard of Paul as a controversial figure, he sets out to explain what he confidently preached as gospel:

I am not ashamed of the gospel; it is the power of God for salvation to everyone who has faith, to the Jew first and also to the Greek. ${ }^{17}$ For in it the righteousness of God is revealed through faith for faith; as it is written, 'The one who is righteous will live by faith'. (1:16-17)

He returns to this claim in the following:

But now, irrespective of law, the righteousness of God has been disclosed, and is attested by the law and the prophets, ${ }^{22}$ the righteousness of God through faith in Jesus Christ for all who believe. (3:21-22)

In between, in 1:18-3:20, he establishes that all have need of God's saving righteousness because all have sinned. The 'all' encompasses both Jews and Gentiles. The inclusion of Jews was an important part of the argument because it enabled him to argue that they need the gospel just as much as Gentiles and their privileged position as bearers of holy tradition did not exempt them from this. We see Paul's intention already in 3:9 where he declares: 'What then? Are we any better off? No, not at all; for we have already charged that all, both Jews and Greeks, are under the power of sin'.

He reaches this point by first declaring God's anger against what all his hearers, as Jews or proselytes, converted Gentiles, would have seen as abhorrent: same-sex intercourse. It was, as we have seen, along with idolatry, one of the aspects of Gentile culture which Jews most despised. By the end of Romans 1, Paul has broadened the focus to all sins. In typically rhetorical style he then turns in 2:1 on hearers who judge others whilst doing the same things themselves. This need not already have Jewish hearers in mind, but by 2:910 he makes it clear that he wants his hearers' assent to the statement that all must face God's judgement and be judged on the same basis, whether they are Jews or Gentiles. He then deals directly with Jews (2:17), consolidating his case that if they, too, are trapped in sin, then, they, too, need the gospel, which Paul has been preaching. He will have more to explain, including what then is left of their special status. 
Our focus is his statements about same-sex intercourse, which, in effect, are incidental to his argument. Had he chosen something else like the closely related drunkenness, we would have been left with virtually nothing about samesex relations in the New Testament. It is not possible to review all the various approaches to Paul's statements here, many of them serving hermeneutical interests in support for or opposition to stances in debates on the issue today.

\section{Recent interpretations}

William Countryman (2007:108-123) rightly notes rejection of same-sex intercourse as one of the markers of being a Jew, along with circumcision and food laws. He suggests that Paul cites such rejection here only to reject it, as he does the demand for circumcision and observance of food laws. Countryman argues that the sins Paul opposes are only those listed at the end of the chapter. But this is not the impression Paul gives when he appears quite serious in correlating the perversion he sees in same-sex intercourse with the perversion he sees when people pervert true understanding of God and turn instead to idols. Dale Martin (2006:59-60, 65-76) suggests that Paul in any case rejects all sexual passion, but this scarcely does justice to Paul's comments elsewhere; for instance, in 1 Corinthians 7 , where Paul is at pains to emphasise that following one's sexual desire to the conclusion that to marry is not a sin. John Boswell (1980:111114), followed by Walter Wink (1999:34-37), had argued that Paul is writing only about heterosexual men who engage in such acts, not homosexuals, but, as we have seen, it is highly unlikely that Paul would have differed from all other Jews of the time whose writings survive, who rejected such distinctions. Nor does it make sense to argue that Paul is only concerned with same-sex acts in cultic contexts (cf. Boswell 1980:108; Hanks 2006:594; Kuefler 2001:255-260). His focus is not just concerning acts but also attitude and ultimately, mind, which is independent of location.

Robin Scroggs (1983:99-139), noting the prominence of sexual predation of the young, suggested that Paul was primarily addressing pederasty, not same-sex relations between consenting adults. But both were roundly condemned by contemporary Jews, and Paul's reference in 1:27 about having passion for one another suggests that he, too, included consenting adults in his judgement. This also counts against restricting the application of Paul's comments to male prostitution. Diane Swancutt (2003:205-206, 2004:43, 70-72) suggests that the charge of hypocrisy which comes in 2:1 suggests that Paul is aware of the critique made against some Roman Stoics that they taught against such practices but were themselves engaged in questionable relations with their students. This scenario is possible, although clearly Paul's primary focus is the issue of the sinfulness of all humanity, including Jews, rather than particular teachers in the imperial city.

Robert Gagnon (2003a:81, 92) differentiates, as do many in current debates, between homosexual orientation and the act of intercourse, arguing that Paul's focus is the latter and not the former. He goes beyond Romans 1 to speculate that Paul would have believed that there were homosexual people and that their condition was a product of the fall (Gagnon 2001:285-86). Such an approach often then serves a hermeneutic which acknowledges same-sex orientation but declares that such people should not give expression to their sexuality because scripture terms it an abomination. What appears an attempt to be kind - namely in recognising the orientation - is in fact very cruel. It is, in any case, likely that Paul along with Philo and other Jews of his time would have rejected the categories homosexual and heterosexual. Philo sees passive partners as damaged by feminisation, but at most acknowledges their state as damaged and in need of repair. As we shall see, Paul sees not just the act but also misdirected and intense passion as a manifestation of sin.

Some give special emphasis to honour-shame values, arguing that Paul's stance derives from the perspective we noted in Philo and elsewhere, that such behaviour undermines masculinity thereby reducing the passive partner to the level of a woman (Mayordomo-Marín 2008:106-109, 115). If so, he nevertheless blames both partners as engaging in shameful behaviour. But like Philo, Paul's stance is also firmly biblically based, as his allusions to Genesis 1:27 and likely allusion to the penalty of death in Leviticus 20:13 indicate (Brooten 1998:283; Gagnon 2001:122; cf. Punt 2008:87). Nevertheless, when Paul deems such behaviour unnatural, he most probably has in mind the way God created 'male and female' (Gn 1:27) to be; for him, that included both what complementarity of genitalia appears to require and what we would recognise as cultural assumptions about behaviour and dress, such as head covering. For Paul, to abandon such marks of gender is to abandon God's ordering of creation (1 Cor 11:13-15).

\section{Examining Romans 1}

\section{Romans 1:24}

Turning directly to the texts, we read the following:

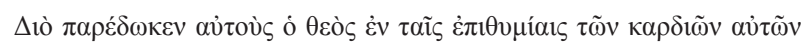

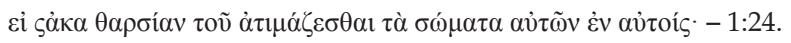
[Therefore God gave them up in the lusts of their hearts to impurity, to the degrading of their bodies amongst themselves.]

$\Delta$ ió [therefore] is explained in the following verse, it is summarised as:

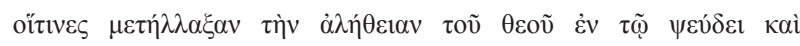

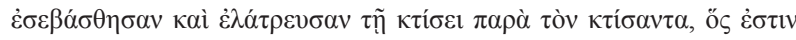

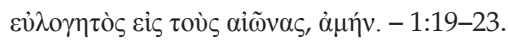

[25because they exchanged the truth about God for a lie and worshipped and served the creature rather than the Creator, who is blessed for ever! Amen.]

As in Wisdom (13:1-14:31; similarly 1 Th 4:5;1 Cor 10:7-8), the argument is that a perverted understanding of God, denying God's true nature, results in a perverted understanding of oneself, denying one's own true nature as male or female. Paul is not citing the fall in the Garden of Eden as the cause, but idolatry; nor is he concerned only with acts in idolatrous contexts. 
Paul repeats various compounds of the word for 'exchange':

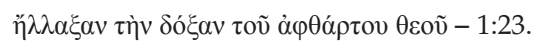

[they exchanged the glory of the immortal God]

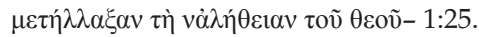

[they exchanged the truth about God]

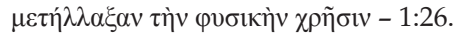

[exchanged natural intercourse]

'God gave them up' means God abandoned them to their sinful perversions, including with a view to their suffering the consequences; in that sense, it is an expression of God's anger. This is not an excuse, as though they cannot help themselves having such a mind with dishonourable desires and passions. On the contrary, as in 1:20, they are $\dot{\alpha} v \alpha \pi \circ \lambda \circ \gamma \tilde{\tau} \tau \mathrm{N} \varsigma$ [without excuse], so that their psychological state in 1:24, 1:26-28 is deemed blameworthy.

$\dot{\varepsilon} v \tau \alpha \tilde{\imath} \varsigma \dot{\varepsilon} \pi \imath \theta v \mu \dot{a}_{\alpha 1 \varsigma} \tau \tilde{\omega} v \kappa \alpha \rho \delta 1 \tilde{\omega} v \alpha v \dot{\tau} \tilde{\omega} v$ [In the lusts of their hearts to impurity] (lit. 'in the desires of their hearts $/$ minds') is the first of three references to sexual desire:

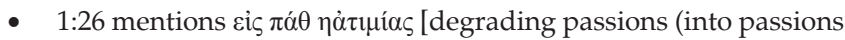
of dishonour)]

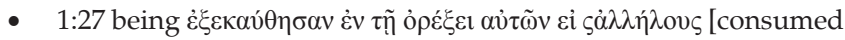
with passion, burning with passion (they burned in passion for one another)].

These passions, as misdirected to their own sex and as excessive are, in Paul's view, not a natural orientation to be tolerated (as God created passions, which are in that sense good and bad only when misdirected), but a perversion to be condemned. Something goes wrong in both mind and action. The danger of intense passion appears then to inform his thought as it did that of many who dabbled in

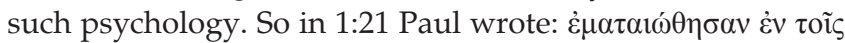

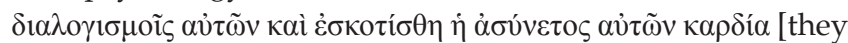
became futile in their thinking and their senseless minds

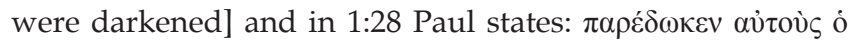

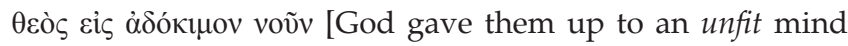
and to things that should not be done]. The focus is not primarily or solely excess, as Martin suggests (2006:58-59), but the misdirection it inevitably entails. It is highly likely that in speaking of men being carried away by passion, Paul has similar scenarios in mind to those mentioned in Philo, namely, parties where people get drunk and engage indiscriminately in profligate acts of sexual indulgence.

When Paul writes here in 1:24 of 'the degrading of their bodies amongst themselves' this dishonouring relates to behaviour which reduces the passive part to the level of a woman, contrary both to society's norms and to creation. غंv $\alpha$

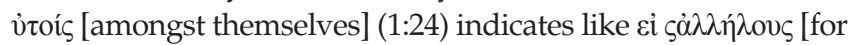
one another] (1:26), that this is mutual and brings shame also on the active partner whose action brings shame to the other.

\section{Romans 1:26}

Paul repeats the claim in the following:

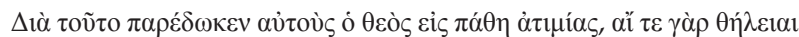

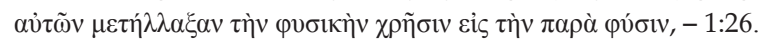

[For this reason God gave them up to degrading passions. Their women (lit. females) exchanged natural intercourse for unnatural.]

The 'their' in 'their females' might refer to men as owning or controlling women, but more probably refers to those human beings as a group who have denied God's reality. Paul would nevertheless share the common view that women belonged to men, so that the phrase probably means more than simply 'the women amongst them'. There is no equivalent phrase to 'their males' in 1:27. Some have seen in the words, 'exchanged natural intercourse for unnatural', a reference to bestiality (Debel 2009:631-640; Haacker 1994:174-175), where women are penetrated by animals, an equally abhorrent notion for Jews, or anal intercourse as a form of contraception. More likely it is a rare reference to same-sex relations between women (Brooten 1998:239-253; Jewett 2007:176), something we noted that both Philo and Pseudo-Phocylides condemned and which was generally abhorred in Greek and Roman culture (Krenkel 2006:438-464; Williams 1999:233-234). When Paul writes of 'natural intercourse' in relation to women, he means their intercourse with men. By contrast, what can be described as 'unnatural' is women having intercourse with women.

\section{Romans 1:27}

Paul continues with the corresponding male behaviour, indicated by ó $\mu$ oí $\omega \varsigma$ [in the same way]:

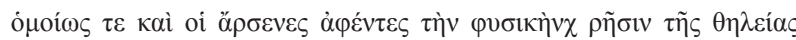

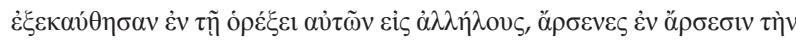

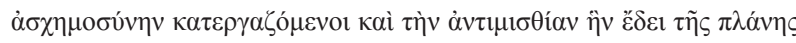

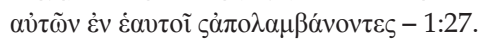

$\left[{ }^{27}\right.$ and in the same way also the men (lit. males), giving up natural intercourse with women (lit. intercourse with the female), were consumed with passion for one another. Men (lit. males) committed shameless acts with men (lit. males) and received in their own persons the due penalty for their error.]

'Natural intercourse' indicates what is natural for men and women. In using the words, 'male' and 'female', Paul alludes to Genesis 1:27, 'male and female he created them', obscured in the New Revised Standard Version. As noted earlier, nature will refer to how Paul understands the divine order of creation, including male and female roles. In Plato's objection to same-sex intercourse as contrary to 'nature', as not 'according to nature', he refers above all to sexual intercourse whose aim is not procreation. As we noted earlier, this is also a major theme in Philo, who shares the worry about wasted semen and depopulation. Although for him, too, 'natural' alludes to how God created male and female (Gn 1:27) and the active and passive roles they are to fulfil in sexual intercourse. Paul nowhere uses the procreation argument to combat sexual wrongdoing, namely homosexual or heterosexual acts. In our age of effective contraception we can easily separate engaging in sexual intercourse as an expression of love and intimacy from doing so also for purposes of procreation. In the ancient world, this was not so. Engaging in sexual intercourse as an expression 
of intimacy and doing so for procreation inevitably belonged more closely together, so that both aspects are usually to be assumed where sexual intercourse is mentioned. On the other hand, both in this passage and elsewhere he addresses sexual issues Paul focuses on the aspect of sexual intimacy, not on procreation, and so does not use the depopulation argument here.

\section{Paul continues:}

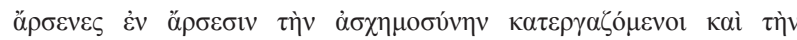

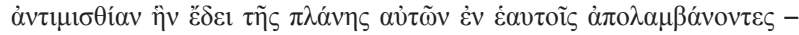
1:27.

[Men (lit. males) committed shameless acts with men (lit. males) and received in their own persons the due penalty for their error.]

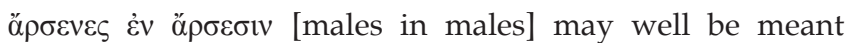
literally and allude to anal intercourse. Again we note the shame motif as in 1:24 ('dishonouring their bodies') and 1:26 ('passions of dishonour'). What the 'due penalty' was which they received for their error, or better, their going astray, is not immediately clear and so has been subject of speculation. I find Robert Jewett's explanation the best so far, that it refers specifically to penis and anal soreness (Jewett 2007:179), but other possibilities include feminisation, waste of money and time, addiction, or lack of fulfilment. Nothing is said of consequences for women.

\section{Romans 1:28-32}

Finally Paul returns to the nub of his argument:

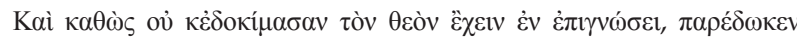

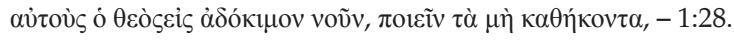

[And because they did not see fit to acknowledge God, God gave them up to an unfit mind and to things that should not be done.]

The reference of 'things that should not be done' is obvious. Again the focus is not just the acts, but the debased mind, the perverted orientation of passions. Paul's focus is always

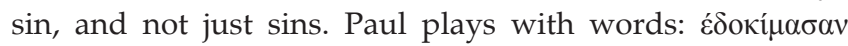

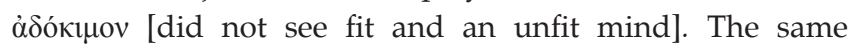
kind of psychological focus appeared in the primary failure to acknowledge God in 1:18-23, where Paul writes:

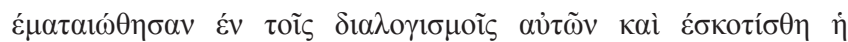

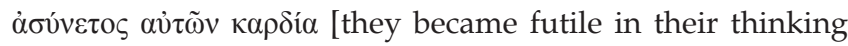
and their senseless minds were darkened] (1:21).

Paul then broadens his scope:

They were filled with every kind of wickedness, evil, covetousness, malice. Full of envy, murder, strife, deceit, craftiness, they are gossips, ${ }^{30}$ slanderers, God-haters, insolent, haughty, boastful, inventors of evil, rebellious towards parents, ${ }^{31}$ foolish, faithless, heartless, ruthless. ${ }^{32}$ They know God's decree, that those who practise such things deserve to die - yet they not only do them but even applaud others who practise them. (1:29-32)

The reference to death may well allude to the death penalty prescribed for same-sex intercourse in Leviticus 20:13.

\section{Romans 1 in perspective}

As Andrie du Toit points out (Du Toit 2003:96-98), Paul is not making same-sex intercourse the pinnacle of all evil, but employing it as an instance to further his argument that all have sinned. We might want to put the greed of the wealthy up there or some other far-reaching evil. Aside from the list in 1 Corinthians 6:9-10, Paul never mentions the topic elsewhere, although it will have been included in his allusions to sexual wrongdoing, which regularly feature.

The temptation to modernise Paul either by explaining away his comments as applicable to only special instances or by transforming his comments on desires into neutral pathology or natural sexual orientation is to be resisted. Paul, almost certainly, believed that all men were heterosexual and that attitudes and behaviours which moved away from what God made men and women as male and female to be and do, were manifestations of gross sin; he assumed his hearers would totally agree with him. I use 'almost' simply because historical reconstruction cannot escape being a matter of probabilities. In this instance, we are well along the high end of the probability scale. Paul's views are to be respected, and make good sense, given his assumptions.

\section{Engaging Paul from a 21st century perspective}

It is quite another question whether we view these common Jewish assumptions as sufficient to account for what we observe today as the phenomenon of people having sexual orientation towards those of their own sex. In some instances, his assessment will be directly applicable. Deliberate perversion, not least in the context of extravagance and abuse of alcohol, has its contemporary equivalents today and should, with Paul, be seen for what it is. There is an increasing acceptance of the view that for others with samesex orientation we are not dealing with such perversion but with what comes close to being their natural state; the matter is complex. The appearance of sexual genitalia seems at first sight to make matters simple, and is a good guide for the majority of the population, but even at a physical level not everyone is born with unambiguous genitalia and beyond that for some, their life-long sexual orientation does not match their appearance and for others the orientation may not remain constant, such complexities giving rise to the acronym GLBTI (Gay, Lesbian, Bisexual, Transgender, Intersex) which can be considered a simplification of reality.

In dealing with such texts today I identify three main options:

1. Embrace Paul's view that the same-sex mind/orientation/ desire and action is a sinful perversion comparable to idolatry.

2. Embrace Paul's view that same-sex acts are sin as Leviticus states, but not his view of sexual orientation, acknowledging that there are some genuinely same-sex oriented people.

3. Not to embrace Paul's view of sexual orientation, thereby acknowledging that there are genuinely samesex oriented people (as Option 2) and encourage them to express their sexuality responsibly on the same basis as heterosexual people. 
We shall discuss each option in turn:

\section{Option 1}

Embrace Paul's view that the same-sex mind/orientation/ desire and action is a sinful perversion comparable to idolatry: Then one should require such people in a spirit of love and compassion not to express their sexuality but to seek healing. Same-sex marriage would be to institutionalise pathology. Leadership in the church is acceptable only when such people embrace celibacy and are well on the way to healing.

\section{Option 2}

Embrace Paul's view that same-sex acts are sin as Leviticus states, but not his view of sexual orientation, acknowledging that there are some genuinely same-sex oriented people: One would nevertheless still require celibacy on the basis that same-sex acts are forbidden and response to same-sex marriage and leadership would be as Option 1. Some like Gagnon argue that this is Paul's option (Gagnon 2003b), but that is based on false assumptions and a denial of Paul's focus which is not just on acts but on orientation. A variation of this view, which lies halfway between Option 1 and 2, is not to embrace Paul's view on sexual orientation but also not to acknowledge that some people are genuinely same-sex in orientation, but see such orientation as pathology. The same consequences follow in relation to same-sex marriage and leadership. This approach avoids the serious ethical problem which arises from the option which accepts same-sex orientation as natural for some but then demands that they should never give expression to it, in other words, practice celibacy - ultimately a cruel and potentially dangerous option.

The serious ethical problem about an approach which concedes that a same-sex orientation may be God-given or at least natural and not evil in itself is that it leaves itself without any viable defence against the charge of injustice when it blocks people from bringing to expression what it agrees are legitimate feelings. Unlike the stance which sees samesex acts as arising from pathology or person and therefore follows the prohibitions in opposing them, it is hard to see why those recognising same-sex orientation and desires as legitimate, oppose their expression in responsible and loving acts of intercourse. With all the biblical and other grounds for seeing them as such surrendered to modern insight in agreeing to the legitimacy of the desires such an approach paints itself into a corner and really has no plausible answer to why the acts must not be allowed. It amounts to upholding the biblical prohibition whilst rejecting its biblical rationale. This then becomes an ethical issue which people advocating it must face. To impose biblical commands whilst rejecting biblical rationales as in Option 2 is to act in a way that seems ethically irresponsible, but it happens where people find themselves unable to engage the biblical record critically. The approach which upholds the prohibitions on the basis of arguing from pathology or as Paul from perversion are not as vulnerable to the charge of lacking ethical integrity.
Sometimes the ethical tension is dramatically evident where, on the one hand, great sensitivity is shown to the queer community, including both listening and presenting their viewpoint in the discussion, even to the point of acknowledging its validity and the complexity of sexual orientation which cannot be reduced to binary alternatives or permanent status, but is diverse and fluid. Then, on the other hand, the compassion and sensitivity hits a roadblock because of a reading of the creation stories, especially of the creation of men and women as only male and female (Gn 1:27), as infallible statements of fact which are treated as necessarily excluding such complexity. No wonder queer people see the gospel as bad news. Yet from Jesus and Paul onwards the Christian movement was characterised by the opposite tendency: to take human situations seriously and give them weight even to the extent of setting biblical commandments aside in favour the greater biblical command of love. People advocating this restrictive stance can end up having more in common with the forces that resisted Jesus and Paul than with Jesus and Paul themselves.

The problem is not that people take Genesis 1:27 about God making men and women as male and female too seriously, but they do not take it seriously enough and see it for what it is in its historical and cultural context. It is true that for centuries the creation stories were read as statement of fact - including according to its narrative context that creation took place circa 6000 years ago over a period of six days, that humans were made from nothing or according to the second story from dust, that woman were made from a man's rib, that weeds and woes and painful birth contractions only came into being then because of an act of disobedience about eating a forbidden fruit. It is also true that our listening to these texts has changed, so that we no longer treat such detail as fact, but allow ourselves to be informed by more recent knowledge. That knowledge includes quite different understandings of creations' age, the evolution of species and geology, but also much more informed understandings of the nature of such creation stories in ancient cultures, including the creative adaptation of such myths in Israel's tradition, which embody profound insights despite their mythological content. To listen and respect such texts does not require that we always agree with them. Good listening is not about agreeing but about hearing what the other is saying and respecting that at points we will agree or not agree and not trying to pretend otherwise. We need to respect what these texts are and neither read into them our modern scientific understandings, nor for dogmatic reasons assert that they are inerrant or adequate accounts of reality. Mostly we have no hesitation in recognising the distance between our understandings and theirs about creation's age and evolution. Therefore to exempt the creation stories' explanations of the origin of sexuality and gender from such listening but apply it only to the other details appears arbitrary and unwarranted. As new information enables us to see that creation is much older and complex, so it enables us to see that reducing humankind to simply male and female in an exclusive sense and denying the fact that the matter is much more complex and includes variation and fluidity, at least around the edges, or suggesting 
this all changed with the first human sin, is inadequate. It is certainly not a sound basis for ethical judgements about what is legitimate or illegitimate in sexual expression. Love and information ought not therefore to allow texts like Genesis 1:27 to function as roadblocks to love and flexibility in the way that does for those espousing Option 2. Such texts need to be taken seriously as belonging to ancient creation stories and weighed and assessed in the same way as all other elements of such stories.

\section{Option 3}

Not to embrace Paul's view of sexual orientation, thereby acknowledging that there are genuinely same-sex oriented people (as Option 2) and encourage them to express their sexuality responsibly on the same basis as heterosexual people: Then they should be treated in the same way as heterosexual people with regard to marriage and leadership in the church in accordance with the biblical values of justice, compassion and non-discrimination. This is by no means a novel approach, but one which people have taken with regard to a number of issues where it has become clear that what biblical writers assumed was either incorrect or needed substantial revision; these issues include cosmogony, cosmology, medicine, demonology, imminent eschatology, reproduction, marriage, slavery, women, divorce, and much else. It also lies at the heart of what constitutes the Christian movement in the first place and was a major factor in its emergence in dispute with the rest of Judaism such as in its setting aside of the biblical requirement of circumcision, which created intense divisions within the Christian movement. Such developments found their precedent in Jesus himself who allowed the biblical command to respond in compassion to those in need to override other demands like Sabbath observance. If there really are people who are genuinely and not pathologically same-sex in their orientation - which now many government legislations acknowledge then embracing Option 3 is an ethically sustainable way to proceed and avoids the injustice entailed in declaring samesex desire as acceptable but then blocking its expression.

I am convinced that for many with same-sex orientation we are not dealing with the perversion which Paul assumes but with what comes close to being their natural state. For them, rather than unbiblically accepting their orientation and then cruelly imposing the biblical prohibition on their expressing their sexuality, I would urge that they treat themselves as seriously and respectfully as should all, whatever their orientation, so that their sexuality is healthily integrated and expressed in loving and caring relationships.

And what about same-sex marriage? If we believe that marriage, as the appropriate context for sexual intercourse, must always leave open the possibility of conception and creating offspring, and so reject contraception, then the inseparability of sexual intercourse for procreation and sexual intercourse as an expression of intimacy and love necessarily excludes extension of marriage to include same-sex couples. If we accept contraception and so accept that marriage need not necessarily be for procreation, but may be for companionship, and sexual intercourse within it as an expression of intimate love (as is the case in many heterosexual marriages), there would seem to me to be no barrier to extending marriage to include same-sex partnerships.

It is a separate question whether same-sex couples should be able to adopt and bring up children, but that has long since been accepted in legislation. It is also a separate, but important, issue how well children are parented, including the balance of their experiences of male and female role models. This should not be confused with the issue of equality of marriage, unless we were to move in the direction of recognising only those partnerships as marriage which are committed to producing and parenting children, marriage as contract for parenthood, which would mean excluding from marriage both heterosexual and homosexual partnerships where that is not the intent. In the ancient world, indeed until the mid-20th century, these options were not on the table as they are today as a result of the availability of effective contraception - an innovation, which has had an enormous impact on society, far beyond the marriage question. It has revolutionised how women have been able to contribute to society; it has radically changed premarital sexual relations. It is also time for us to recognise that it now makes recognition of committed long term same-sex relations as inevitable and right.

There is wise precedent for applying the biblical principle of love and care in relation to biblical commands and the assumptions of biblical writers which are no longer seen as valid, applicable or sufficiently comprehensive. Jesus prioritised love over other requirements, for instance, ' $[t]$ he Sabbath was made for people not people for the Sabbath' (Mk 2:27) and met with stiff resistance from the pious who found this intolerable (Mk 2:1-3:6). In the early church in NT times, there was intense struggle between those who argued for setting circumcision aside and those who insisted on upholding all biblical commands, including circumcision of Gentiles as enjoined in Genesis 17.

The Church in more recent centuries has had to adjust similarly to departing from some biblical prohibitions, not out of lack of faith, but in view of the biblical principle of love and the model of taking new situations and knowledge into account. The result has been changed approaches to slavery, women (their status and roles, including leadership in the church), and to provisions forbidding divorce, remarriage, and remaining married after adultery and much more.

Respecting biblical writers includes acknowledging distance as well as embracing proximity. This applies also to what is said about same-sex relations. There should be no discrimination against same-sex oriented people in any aspect of life, and that includes in marriage and holding positions of responsible leadership. The same criteria should apply in every situation, whether a person is heterosexual or homosexual. This would seem to be, at the very least, natural justice, and a Christian response which embraces the biblical value of love, should never lag behind that. 


\section{Acknowledgements Competing interests}

The author declares that he has no financial or personal relationship(s) that may have inappropriately influenced him in writing this article.

\section{References}

Botha, P.H. \& Van Rensburg, F., 2004, "Homosexuality as "against nature": An interpretation of Romans 1:26-27', Acta Patristicaet Byzantina 15, 38-56.

Boswell, J., 1980, Christianity, social tolerance, and homosexuality: Gay people in Western Europe from the beginning of the Christian era to the fourteenth century, University of Chicago Press, Chicago.

Brinkschröder, M., 2003, 'Die karriere des homosexualitäts verbotsim Diaspora judentum: Ehebruch und päderastiezwischen heiligkeitsgesetz und dekalog', in B. Heininger (ed.), Geschlechterdifferenz in religiösen Symbolsystemen, pp. 158-169, LIT, Münster.

Brooten, B.J., 1998, Love between women: Early Christian responses to female homoeroticism, Chicago University Press, Chicago.

Countryman, L.W., 2007, Dirt, greed, and sex: Sexual ethics in the New Testament and their implications for today, 2nd edn., Fortress, Minneapolis.

Debel, H., 2009, "'Unnatural intercourse" in Rom 1,26-27: Homosexual or heterosexual?', in U. Schnelle (ed.), The letter to the Romans, pp. 637-640, Peeters, Leuven.

Du Toit, A.B., 2003, 'Paul, homosexuality and Christian ethics', in D.E. Aune (ed.) Neotestamentica et philonica: Studies in honour of Peder Borgen, pp. 92-107, Brill, Leiden.

Fredrickson, D.E., 2000, 'Natural and unnatural use in Romans 1:24-27: Paul and the philosophic critique of Eros', in D.L. Balch (ed.), Homosexuality, science, and the 'plain sense' of Scripture, pp. 197-222, Eerdmans, Grand Rapids.

Gagnon, R.A.J., 2001, The Bible and homosexual practice: Texts and hermeneutics, Abingdon, Nashville.

Gagnon, R.A.J., 2003a, 'The Bible and homosexual practice: Key issues', in D.O. Via \& R.A.J. Gagnon (eds.), Homosexuality and the Bible: Two views, pp. 40-92, Fortress, Minneapolis.

Gagnon, R.A.J., 2003b, 'Response to Dan O. Via', in D.O. Via \& R.A.J. Gagnon (eds.), Homosexuality and the Bible: Two views, pp. 99-105, Fortress, Minneapolis.

Haacker, K., 1994, 'Exegetische Gesichtspunktezum Thema Homosexualität', Theologische Beiträge 25, 173-180.

Hanks, T., 2006, 'Romans', in D. Guest, R.E. Goss, M. West \& T. Bohache (eds.), The Queer Bible commentary, pp. 582-605, SCM, London.

Jewett, R., 2007, Romans, Fortress, Minneapolis.

Krenkel, W., 2006, 'Naturalia non turpia. Sex and gender in ancient Greece and Rome', in W. Bernard \& C. Reitz (eds.), Schriften zurantiken Kultur und Sexualwissenschaft, Spudasmata: Studien zur Klassischen Philologie und ihren Grenz gebieten 113 Georg OlmsVerlag, Hildesheim.

Kuefler, M., 2001, The manly eunuch: Masculinity, gender ambiguity, and Christian ideology in late antiquity, University of Chicago Press, Chicago.

Loader, W., 2007, Enoch, Levi, and Jubilees on sexuality: Attitudes towards sexuality in the early Enoch literature, the Aramaic Levi document, and the Book of Jubilees, Eerdmans, Grand Rapids.
Loader, W., 2009, The Dead Sea Scrolls on sexuality: Attitudes towards sexuality in sectarian and related literature at Qumran, Eerdmans, Grand Rapids.

Loader, W., 2011a, The pseudepigrapha on sexuality: Attitudes towards sexuality in Apocalypses, Testaments, Legends, Wisdom, and related literature, Eerdmans, Grand Rapids.

Loader, W., 2011b, Philo, Josephus, and the testaments on sexuality: Attitudes towards sexuality in the writings of Philo, Josephus, and the testaments of the Twelve Patriarchs, Eerdmans, Grand Rapids.

Loader, W., 2012, The New Testament on sexuality, Eerdmans, Grand Rapids.

Loader, W., 2013, Making sense of sex: Attitudes towards sexuality in early Judaism and Christianity, Eerdmans, Grand Rapids.

Martin, D.B., 2006, 'Heterosexism and its Interpretation of Romans 1:18-32', in D.B. Martin (ed.), Sex and the single savior: Gender and sexuality in biblical interpretation, pp. 51-64, Westminster John Knox, Louisville.

Martin, D.B., 2006, 'Paul without Passion: On Paul's rejection of desire in sex and marriage', in D.B. Martin (ed.), Sex and the single savior: Gender and sexuality in biblical interpretation, pp. 65-76, Westminster John Knox, Louisville.

Mayordomo-Marín, M., 2008, 'Konstruktionen von Männlichkeit in der Antike und der paulinischenKorintherkorrespondenz', Evangelische Theologie 68, 99-115.

Nolland, J., 2000, 'Romans 1:26-27 and the homosexuality debate', Horizons in Biblical Theology 22, 32-57.

Petersen, W.L., 1986, 'Can ARSENOKOITAI be translated by "homosexuals"? (1 Cor 6:9; $1 \mathrm{Tim}$ 1:10)', Vigiliae christianae 40, 187-191.

Punt, J., 2008, 'Sin as sx or sex as sin? Rom 1:18-32 as first century CE theological argument', Neotestamentica 42, 73-92.

Schoedel, W.R., 2000, 'Same-sex Eros: Paul and the Greco-Roman tradition', in D.L. Balch (ed.), Homosexuality, science, and the 'plain sense' of Scripture, pp. 43-72, Eerdmans, Grand Rapids.

Scroggs, R., 1983, The New Testament and homosexuality: Contextual background for contemporary debate, Fortress, Philadelphia.

Swancutt, D.M., 2003, "The disease of effemination": The charge of effeminacy and the verdict of God (Romans 1:18-2:16)', in S.D. Moore \& J.C. Anderson (eds.), New Testament Masculinities, pp. 193-234, Semeia St, SBL, Atlanta.

Swancutt, D.M., 2004, 'Sexy stoics and the rereading of Romans 1.18-2.16', in A.J. Levine \& M. Blickenstaff (eds.), A feminist companion to Paul, pp. 42-73, T\&T Clark, London.

Theobald, M., 2000, 'Das Argument "contra naturam" und die Homosexualität, 1,26f): Zurethischen Normativität der Schöpfungsordnung', in M. Theobald (ed.), Der Römerbrief, Erträge der Forschung 294, pp. 142-147, Wissenschaftliche Buchgesellschaft, Darmstadt.

Via, D.O., 2003, 'The Bible, the Church, and homosexuality' and 'Response to Robert A.J. Gagnon', in D.O. Via \& R.A.J. Gagnon (eds.), Homosexuality and the Bible: Two views, pp. 1-39, 93-98, Fortress, Minneapolis.

Vorster, J.N., 2006, 'The making of male same-sex in the Graeco-Roman world and its implications for the interpretation of biblical discourses', Scriptura 93, 432-454.

Williams, C.A., 1999, Roman homosexuality: Ideologies of masculinity in classical antiquity, Oxford University Press, Oxford.

Wink, W., 1999, 'Homosexuality and the Bible', in W. Wink (ed.), Homosexuality and Christian faith: Questions of conscience for the churches, pp. 33-49, Fortress, Minneapolis.

Winterer, A.,2005, VerkehrteSexualität - einumstrittenesPauluswort: EineexegetischeStudiezuRöm. 1,26f. in der Argumentationsstruktur des Römerbriefes und imkulturhistorisch-sozialgeschichtlichenKontext, Europäische Hochschulschriften Reihe XXIII, 810, Peter Lang, Frankfurt.

Wright, D.F., 1984, 'Homosexuals or prostitutes? The meaning of ARSENOKOITAI (1 Cor 6:9; 1 Tim 1:10)', Vigiliae christianae 38, 124-153. 